\title{
Socio-economic status of fishermen operating FRP boats in Nagapattinam District, Tamil Nadu: a special focus on poverty and income inequality
}

\author{
P. JEYANTHI, S. BALASUBRAMANIAM AND J. CHARLES JEEVA \\ ICAR-Central Institute of Fisheries Technology, Matsyapuri P.O., Kochi - 682 029, Kerala, India \\ e-mail: tvjeyanthi@gmail.com
}

\begin{abstract}
Socio-economic status is a major indicator of livelihood and the two crucial factors determining livelihood are poverty and income inequality. The present study assessed the livelihood status of fishermen operating fibre re-inforced plastic (FRP) boats (motorised) of 9-10 $\mathrm{m} \mathrm{L}_{\mathrm{OA}}$. Socio-economic status, including poverty and income inequality of fishermen, comprising both owners $\left(\mathrm{FRP}_{\mathrm{O}}\right)$ and labourers $\left(\mathrm{FRP}_{\mathrm{L}}\right)$ of FRP boats were estimated. The average daily per capita income earned by $\mathrm{FRP}_{\mathrm{O}}$ and $\mathrm{FRP}_{\mathrm{L}}$ were $₹ 1256$ and $₹ 105$ respectively. It was low for $\mathrm{FRP}_{\mathrm{L}}$ during low income level and was almost same as the poverty line described by World Bank ( $\$ 1.25$ per day). The Gini-coefficient revealed high level of income equality among the fishermen. The quintile income distribution of $20 \%$ of the richest and poorest indicate no inequality among the fishermen operating FRP boat.
\end{abstract}

Keywords: Expenditure, FRP boat, Income inequality, Poverty, Socio-economic status

Fishing is a highly unorganised and unregulated activity which provides employment and livelihood to millions of fisherfolk either directly or indirectly. Small scale fishing communities are the poorest and most disadvantaged population in the world (Bene et al., 2000). Fishermen earn comparatively less income than others in low skill jobs (Scott, 1954). Poverty is one of the major threats to the fishermen communities and is still an unsolved social issue in many of the developing countries, particularly in Asia and Africa. Kurien (2005) stated that at the global level about 5.8 million small scale fishers earn less than US\$1 per day and continue to be in a state of poverty. The present study was conducted in Nagapattinam District of Tamil Nadu, for assessing the socio-economic status of fishermen operating motorised fibre glass reinforced plastic (FRP) boats with special emphasis on poverty and income inequality.

Nagapattinam is one of the coastal districts in Tamil Naduhaving 23,541 active fishermen of which 2,002 use motorised FRP boats (CMFRI, 2005). After the tsunami that struck the coast in December 2004, the conversion of wooden catamarans into FRP crafts and supply of FRP crafts as part of rehabilitation measures paved a new future for FRP crafts in this area (Jeeva et al., 2011). The present study was based at two coastal villages namely, Akkaraipettai and Kechankuppam in Nagapattinam District. Motorised FRP boats with 9 - $10 \mathrm{~m} \mathrm{~L}_{\mathrm{OA}}$ using outboard engine were selected for the study. Data collected separately from 120 fishermen comprised 60 FRP boat owners (FRP ${ }_{\mathrm{O}}$ ) and 60 FRP boat labourers $\left(\mathrm{FRP}_{\mathrm{L}}\right)$ using random sampling method. The data included important socio-economic variables viz., age, education, family size, number of earning persons in a family, monthly income, housing type, social association and expenditure pattern.

Percentage analysis was used to assess the socio-economic characteristics, income and expenditure. Poverty among the fishermen operating FRP boats was assessed using single economic criterion i.e., per capita income (PCI). As adopted by World Bank, for international comparisons, $\$ 1.25$ per day PCI was selected as poverty line in the present study (World Bank, 2005). Poverty calculation for both the minimum and maximum income levels of fishermen were done following the World Bank method of estimation.

Even though, poverty is considered as a multi-dimensional phenomenon, lack of income is considered as a standard measure of estimating poverty (Makoka and Kaplan, 2005). An attempt was made towards assessing the income inequality using Gini coefficient with reference to Lorenz curve (Khattak and Hussain, 2008) and 20\% poorest and richest quintile income among the fishermen (Coudouel, 2002).

Majority of the fishermen were above 35 years of age. Among $\mathrm{FRP}_{\mathrm{O}}$, majority (38.33\%) had completed middle school level of education while among $\mathrm{FRP}_{\mathrm{L}}$ majority (43\%) had only primary level of education. Higher 
education was low (less than 5\%) due to maximum middle school level drop outs mostly due to economic compulsion to support their family at young age (Table 1). Illiteracy was high among $\mathrm{FRP}_{\mathrm{L}}(31 \%)$.

Nuclear family is the predominant family type, with maximum four members. Social development programmes of Government of Tamil Nadu have greatly influenced the structural change from joint to nuclear families (Narayanakumar and Krishnan, 2013). The average fishing experience was 19 and 23 years in $\mathrm{FRP}_{\mathrm{O}}$ and $\mathrm{FRP}_{\mathrm{L}}$ respectively. Housing is an important socio-economic indicator with high proportion of tiled houses for FRP $(48.33 \%)$ and $\mathrm{FRP}_{\mathrm{L}}(76.34 \%)$. About $45 \%$ under $\mathrm{FRP}_{\mathrm{O}}$ category resided in concrete houses.

Table 1. Socio-economic characteristics of fishermen operating FRP boat

\begin{tabular}{lll}
\hline Particulars & $\mathrm{FRP}_{\mathrm{O}}(\mathrm{n}=60)$ & $\mathrm{FRP}_{\mathrm{L}}(\mathrm{n}=60)$ \\
\hline $\begin{array}{l}\text { Age } \\
\text { Education (\%) }\end{array}$ & $36 \mathrm{yr}$ & $38 \mathrm{yr}$ \\
i. Illiterate & 25.00 & 31.00 \\
ii. Primary level & 31.67 & 43.00 \\
iii. Middle level & 38.33 & 22.00 \\
iv. High school level & 5.00 & 4.00 \\
Type of family (\%) & & \\
i. Nuclear & 65.00 & 56.00 \\
ii. Joint & 35.00 & 44.00 \\
Family size & 3 & 4 \\
Experience in fishing & $19 \mathrm{yr}$ & $23 \mathrm{yr}$ \\
Housing type (\%) & & \\
i. Thatched & 6.67 & 12.53 \\
ii. Tiled & 48.33 & 76.34 \\
iii. Concrete & 45.00 & 11.13 \\
Monthly income (₹) & 31406 & 2617 \\
Membership of SHGs (\%) & 36 & 16 \\
Women involvement (\%) & 49 & 46
\end{tabular}

The average daily income of $\mathrm{FRP}_{\mathrm{L}}$ was $₹ 105$ which was relatively less than $\mathrm{FRP}_{\mathrm{O}}(₹ 1,256)$ and was less when compared to the minimum wages of various other employments viz., coir manufacturing and food processing industry in Tamil Nadu (GOI, 2011). The average monthly income of $\mathrm{FRP}_{\mathrm{O}}$ was $₹ 31,406$ and the same for the $\mathrm{FRP}_{\mathrm{L}}$ was ₹ 2,617 (Table 2). The annual income ranged between $₹ 1,24,800$ and $₹ 1,96,800$ for $\mathrm{FRP}_{\mathrm{O}}$ and between ₹10,400 and ₹ 16,400 for $\mathrm{FRP}_{\mathrm{L}}$.

The expenditure of $\mathrm{FRP}_{\mathrm{O}}$ and $\mathrm{FRP}_{\mathrm{L}}$ showed priority in the order of spending towards: food, education, fishing, health, entertainment and other heads Maximum spending was on food and the proportion of income spent on food was more among $\mathrm{FRP}_{\mathrm{L}}(57 \%)$ compared to the $\mathrm{FRP}_{\mathrm{O}}(44 \%)$ as stated by Engel's law of expenditure while describing the expenditure pattern of various income groups (Syrovatka, 2003). Both groups spend considerable proportion on education (16 and $18 \%$ respectively). Expenditure on fishing accounted for $16 \%$ in case of FRP ${ }_{0}$.

Poverty analysis indicated that the PCI of FRP $\mathrm{L}_{\mathrm{L}}$ was near to poverty line while considering the average daily PCI at minimum income levels. They were also at high risk as the difference between the daily PCI and World Bank poverty line was between $\$ 0.25$ to $\$ 1$ (Table 2). It was observed that the major reason for poverty among fishermen was lack of knowledge to mobilise earnings and lack of saving and investment habit (Abila et al., 2006). The quintile income distribution of $20 \%$ of the richest and poorest indicate no inequality among the fishermen operating FRP boat (Table 3).

The study revealed that the fishermen operating FRP boat in two selected villages in Nagapattinam District were poor with a low socio-economic condition. This study highlights the vulnerability of FRP fishermen labourers to poverty. Even though, fishing is an open access activity

Table 2. Income details of fishermen operating FRP boat

\begin{tabular}{|c|c|c|c|c|c|c|}
\hline \multirow{2}{*}{ Particulars } & \multicolumn{2}{|c|}{ FRPo } & \multicolumn{2}{|c|}{$\mathrm{FRP}_{\mathrm{L}}$} & \multicolumn{2}{|c|}{ Total } \\
\hline & Min & Max & Min & Max & FRPo & $\mathrm{FRP}_{\mathrm{L}}$ \\
\hline PCI per day (₹) & 975 & 1538 & 81 & 128 & 1256 & 105 \\
\hline PCI per day (\$.) & 17.95 & 28.30 & 1.50 & 2.36 & 23.13 & 1.93 \\
\hline Monthly PCI (₹) & 24375 & 38438 & 2031 & 3203 & 31406 & 2617 \\
\hline Annual PCI (₹) & 124800 & 196800 & 10400 & 16401 & 160800 & 13400 \\
\hline
\end{tabular}

Table 3. Quintile income distribution of the fishermen operating FRP boat

\begin{tabular}{lllllll}
\hline \multirow{2}{*}{ Category } & \multicolumn{5}{c}{ Quintiles } & \multirow{2}{*}{ Poorest/ Richest Ratio } \\
\cline { 2 - 6 } & Poorest & Second & Middle & Fourth & Richest & \\
\hline FRP $_{\mathrm{O}}$ & $305378(18 \%)$ & $318858(19 \%)$ & $329415(20 \%)$ & $340136(21 \%)$ & $358387.30(22 \%)$ & 0.85 \\
FRP $_{\mathrm{L}}$ & $28346(19 \%)$ & $29511(19 \%)$ & $30395(20 \%)$ & $31645.25(21 \%)$ & $31928(21 \%)$ & 0.89 \\
\hline
\end{tabular}


with high competitiveness; there was no peculiar pattern of unequal income distribution among the fishermen. The awareness and knowledge level of fishermen towards the adoption of innovative fisheries technologies and exposure to alternative livelihood opportunities other than fishing must be enhanced in order to improve the socio-economic condition of the fishermen and to considerably enhance their livelihood status.

\section{Acknowledgements}

The authors are thankful to the Director, ICAR CIFT, Kochi for permission to publish this paper. Thanks are also due to the presidents of Akkaraipettai and Kechankuppam village panchayats, Nagapattinam District, Tamil Nadu for their support during data collection for the study.

\section{References}

Abila, R. O., Omwega, R. N. and Lwenya, C. 2006. Fishing and poverty levels around Lake Victoria (Kenya), In: Odada, Eric and Olago, Daniel, O. (Eds.), Proceedings of the $11^{\text {th }}$ World Lakes Conference, vol. 2 p. 193-199. (URL:http:// www.oceandocs.org/bitstream/1834/1495/1/WLCK-193199.pdf)

Bene, C., Mindjimba, K., Belal, E. and Jolley, T. 2000. Evaluating livelihood strategies and the role of inland fisheries in rural development and poverty alleviation: The case of the Yaere floodplain in North Cameroon, IIFET Proceedings, 15 pp.

CMFRI, 2005. National marine fisheries census, Kochi Volume IIa. Ministry of Agriculture and Central Marine Fisheries Research Institute,

Coudouel, A., Hentschel, J. S. and Wodon, Q. T. 2002. Poverty measurement and analysis, In: A sourcebook for poverty reduction strategies, World Bank, vol. 1. Washington, DC, $74 \mathrm{pp}$

Datta, S. K. and Kundu, R. 2007. Socio-economic appraisal of culture based fishermen: Case study in West Bengal, J. Soc. Sci., 15(3): 255-262.
Government of India 2011. Report on the working of the minimum wages act 1948, Ministry of Labour and Employment, Labour Bureau. http://labourbureau.nic.in/ Min_Wages_Report_2011.pdf. (Accessed 24 February, 2014).

Jeeva, J. C., Balasubramaniam, S., Jeyanthi, P. and Ashaletha, S. 2011. Evaluation of the post-tsunami scenario with reference to fishing technology and socio-economic conditions among the motorized craft operators in Tamil Nadu. Indian J. Fish. 58(3): 117-123.

Khattak, N. R. and Hussain, A. 2008. An assessment of the inequality in income and land holdings among rural rice farmers of district Swat. Sarhad J. Agric., 24(1\&2): 187-189.

Kurien, J. 2005. Responsible fish trade and food security. FAO fisheries technical paper, No. 456. Rome, 102 pp.

Makoka, D. and Kaplan, M. 2005. Poverty and vulnerabilityAn interdisciplinary approach, MPRA Paper No. 6964, $33 \mathrm{pp}$.

Narayanakumar, R. and Krishnan, M. 2013. Socio-economic assessment of seaweed farmers in Tamil Nadu - A case study in Ramanathapuram District. Indian J. Fish., 60(4): 51-57.

Scott, H. G. 1954. The economic theory of a common-property resource; the fishery. J. Polit. Econ., 62: 124-142.

Singh, K. 2006. Relative and marginal effects of fish production on family income inequality in Tripura: Decomposition of Gini by income sources. Agri. Econ. Res. Rev., (19): 353-366.

Syrovatka, P. 2003. Food expenditures of Czech households and Engel's law. Agric. Econ. Czech., 49(10): 487-495.

World Bank 2005. Turning the tide. Saving fish and fishers: Building sustainable and equitable fisheries governance. The World Bank, Washington, DC, USA, 20 pp. www. seaweb.org/resources/documents/reports_turningtide.pdf. (Accessed 24 February 2014). 